\title{
EFEKTIVITAS AUDIT INTERNAL TERHADAP KINERJA PERUSAHAAN (STUDI KASUS PADA PERUSAHAAN PDAM GIRI MENANG)
}

\author{
Harum Susanti \\ hrmsusanti@gmail.com \\ Jurusan Akuntansi Fakultas Ekonomi dan Bisnis Universitas Mataram \\ Wirawan Suhaedi \\ wirawan.suhaedi@unram.ac.id \\ Jurusan Akuntansi Fakultas Ekonomi dan Bisnis Universitas Mataram \\ Nur Fitriyah \\ nurfitriyah@unram.ac.id \\ Jurusan Akuntansi Fakultas Ekonomi dan Bisnis Universitas Mataram
}

\begin{abstract}
Abstrak
Penelitian ini menguji pengaruh profesionalisme auditor internal, kualitas audit, dan sistem pengendalian internal terdahap kinerja perusahaan pada PDAM Giri Menanag Mataram. Metode yang digunakan pada penelitian ini yaitu dengan survey menggunakan kuisioner. Sampel pada penelitian ini berjumlah 50 responden yang terdiri dari 13 orang manajer dan 37 orang pegawai tetap. Data diolah menggunakan software SPSS versi 23. Hasil dari penelitian ini menunjukkan bahwa profesionalisme auditor internal tidak memiliki pengaruh terhadap kinerja perusahaan, sedangkan untuk variabel kualitas audit dan sistem pengendalian internal menunjukkan adanya pengaruh terhadapat kinerja perusahaan. Temuan dalam penelitian menunjukkan bahwa profesioanalisme auditor internal belum mampu untuk meningkatkan kinerja perusahaan karena kurangnya rasa percaya diri atau tingkat keterampilan profesional auditor akan pentingnya pekerjaan disebabkan kurangnya hubungan dengan rekan seprofesi sehingga kurang bisa membangun kesadaran profesional. Adanya audit dilakukan secara berkualitas dan sesuai dengan standar yang ada, maka laporan audit yang dihasilkan akan layak untuk dijadikan acuan dalam menilai kinerja perusahaan. Selain itu semakin baik sistem pengendalian internal yang diterapkan dalam perusahaan maka kinerja perusahaan PDAM Giri Menang Mataram juga akan semakin baik.
\end{abstract}

Kata kunci: Profesionalisme Auditor Internal, Kualitas Audit, Sismtem Pengendalian Internal, Kinerja Perusahaan

\section{PENDAHULUAN}

Di Indonesia masalah air bersih adalah tanggung jawab Perusahaan Daerah Air Minum (PDAM) sebagai penyedia air bersih dan air minum. PDAM sebagai Badan Usaha Milik Daerah (BUMD) senantiasa memberi harapan bagi masyarakat untuk memperoleh air bersih. Namun, tidak dapat dipungkiri PDAM juga sebagai perusahaan tentu berorientasi pada bisnis dan profit, dengan mengutamakan ketersediaan air minum dan air bersih secara berkelanjutan. Sebagai salah satu sumber air masyarakat di Indonesia, PDAM tidak lepas dari berbagai masalah baik masalah eksternal maupun internal yang mempengaruhi kinerja perusahaan itu sendiri.

Menurut pendapat dari bagian audit internal di PDAM Giri Menang beberapa permasalahan yang banyak terjadi pada PDAM di Indonesia diantaranya rendahnya tarif yang ditetapkan sehingga perusahaan tidak mencapai tarif Full Cost Recovery (FCR), tarif FCR bermakna bahwa tarif rata-rata PDAM mampu memenuhi biaya dasar atau minimal sama dengan biaya dasar PDAM. Jika PDAM terus menerus menerapkan tarif dibawah HPP (Harga Pokok Produksi) maka lambat laun akan mengganggu keberlangsungan perusahaan tersebut. Kemudian Kehilangan air atau Non Revenue Water (NRW) telah 
menjadi permasalahan umum bagi PDAM di Indonesia seperti yang diungkapkan oleh Ir.Sri Hartoyo, Dipl. SE, ME pada buku Laporan Kinerja PDAM tahun 2017. Kehilangan air ini tidak hanya menyebabkan kerugian finansial PDAM, tetapi juga menyebabkan permasalahan lain seperti diantaranya berkurangnya volume suplai air ke pelanggan, hingga pemasalahan tekanan yang merugikan pelanggan dan pada akhirnya berpengaruh negatif terhadap tingkat kinerja PDAM.

Untuk meningkatkan kinerja perusahaan, penerapan internal audit sangat penting dilakukan dikarenakan pemeriksaan ini menyediakan alternatif yang berkontribusi dalam memecahkan masalah, membantu lembaga dalam mencapai tujuan dan rekomendasi audit akan direncanakan untuk dilakukan perbaikan serta pengembangan lebih lanjut. Menurut Ratu dan Haryono (2018) pengendalian internal merupakan cara manajeman untuk mengelola transaksi bisnis dan aktivitas bisnis secara terkendali dengan tujuan melindungi aset, menghasilkan informasi yang handal, dipatuhinya peraturan perusahaan, dan peraturan pemerintah, serta menghasilkan efektivitas dan efisiensi operasi. Tindakan personel dalam perusahaan untuk menciptakan pengendalian internal dituangkan dalam sistem informasi. Sistem pengendalian internal dapat memperlancar aktivitas operasional perusahaan meliputi aktivitas penjualan, pembelian, produksi, dan aktivitas finansial lainnya, sehingga mendukung transaksi yang cepat, informasi yang akurat, serta meningkatkan efisiensi penggunaan sumber daya. Penelitian ini telah banyak dilakukan sebelumnya, diantaranya adalah Vera (2014), Zulkarnain (2013), Dahir (2016), Benson (2018), Hassan (2016), dan Nanda dkk (2017) menyatakan bahwa hasil dari penelitian menunjukkan bahwa sistem pengendalian intern memiliki pengaruh signifikan dan positif terhadap kinerja perusahaan.

Efektifitas dan efisiensi suatu perusahaan yang terwujud dari sistem pengendalian internal tidak akan berjalan dengan baik apabila tidak adanya profesionalisme auditor yang dapat mengendalikan serta mengevaluasi pengendalian internal yang dilihat dari aktivitas bisnis suatu perusahaan. Profesionalisme auditor adalah seorang auditor harus memiliki tingkat keterampilan yang umumnya dimiliki oleh auditor pada umumnya dan harus menggunakan keterampilan tersebut dengan kecermatan dan keseksamaan yang wajar (Ramadika dkk, 2014). Penelitian sebelumnya telah dilakukan oleh Pernilla et al.,(2013) dimana penelitian tersebut mempunyai hasil bahwa profesional auditor internal berpengaruh positif terhadap kinerja perusahaan.

Audit internal yang dilakukan sesuai dengan standar audit yang berkualitas tinggi dapat mempromosikan penerapan standar akuntansi oleh entitas pelaporan dan membantu memastikan bahwa laporan keuangan mereka dapat diandalkan, transparan, dan bermanfaat (Farouk \& Hassan, 2014). Penelitian yang dilakukan oleh Selma Zekaj (2018) dan Dahir (2016) memiliki hasil yang menyatakan bahwa kualias audit berpengaruh signifikan terhadap kinerja perusahaan. Dewi (2017) melakukan penelitian dengan hasil bahwa kualitas audit internal berpengaruh namun tidak signifikan terhadap kinerja perusahaan. Sedangkan untuk Sayyar (2015) melakukan penelitian dengan hasil bahwa kualitas audit tidak berpengaruh terhadap kinerja perusahaan.

\section{Landasan Teori}

\section{Teori Keagenan (Agency Theory)}

Jensen dan Meckling (1976) juga menyatakan bahwa masalah agensi disebabkan karena terjadinya konflik kepentingan dan asimetri informasi antara prinsipal dan agen. Asimetri informasi merupakan ketidakseimbangan akibat distribusi informasi yang tidak merata dia antara prinsipal dan agen. Permasalahan yang timbul akibat adanya perbedaan kepentingan antara principal dan agent disebut dengan agency problems. 
Dalam penelitian ini dijelaskan bahwa perusahan bertindak sebagai principal dan auditor internal adalah bertindak sebagai agen. Agar tidak terjadi konflik keagenan maka perusahaan yang bertidak sebagai principal harus memberikan apa saja yang dibutuhkan oleh auditor dan pihak yang memberikan jasa akuntansi serta memberikan insentif yang sesuai dengan kesepakatan bersama dari masing-masing pihak. Begitu pula auditor dan pihak yang memberikan jasa akuntansi yang bertidak sebagai agen harus dapat menyelesaikan kewajibannya dengan baik dan memberikan hasil yang memuaskan.

\section{Profesionalisme Auditor Internal}

Profesionalisme auditor adalah seorang auditor harus memiliki tingkat keterampilan yang umumnya dimiliki oleh auditor pada umumnya dan harus menggunakan keterampilan tersebut dengan kecermatan dan keseksamaan yang wajar (Ramadika dkk, 2014). Sebagai profesional, auditor mengakui tanggung jawabnya terhadap masyarakat, terhadap klien, dan terhadap rekan seprofesi, termasuk untuk berperilaku yang terhormat, sekalipun ini merupakan pengorbanan pribadi.

\section{Kualitas Audit}

Kualitas audit sebagai probabilitas gabungan untuk mendeteksi dan melaporkan kesalahan yang material dalam laporan keuangan (Christiani \& Nugrahanti, 2014).Hasil audit pelaksanaan pengelolaan keuangan daerah dikatakan berkualitas jika hasil pemeriksaan (audit) dapat meningkatkan bobot pertanggungjawaban atau akuntabilitas, serta dapat memberikan informasi pembuktian ada tidaknya penyimpangan dari standarstandar audit di sektor pemerintahan.

\section{Sistem Pengendalian Internal}

Menurut Ratu dan Haryono (2018) pengendalian internal merupakan cara manajeman untuk mengelola transaksi bisnis dan aktivitas bisnis secara terkendali dengan tujuan melindungi aset, menghasilkan informasi yang handal, dipatuhinya peraturan perusahaan, dan peraturan pemerintah, serta menghasilkan efektivitas dan efisiensi operasi. Tindakan personel dalam perusahaan untuk menciptakan pengendalian internal dituangkan dalam sistem informasi.

\section{Kinerja Perusahaan}

Kinerja perusahaan adalah suatu tampilan keadaan secara utuh atas perusahaan selama periode waktu tertentu, merupakan hasil atau prestasi yang dipengaruhi oleh kegiatan operasional perusahaan dalam memanfaatkan sumber daya-sumber daya yang dimiliki. Kinerja merupakan suatu istilah secara umum yang digunakan untuk sebagian atau seluruh tindakan atau aktivitas dari suatu organisasi pada suatu periode dengan referensi pada jumlah standar seperti biayabiaya masa lalu atau yang diproyeksikan, dengan dasar efisiensi, pertanggungjawaban atau akuntabilitas manajemen dan semacamnya (Srimindarti, 2004).

\section{Pengembangan Hipotesis}

H1 : Profesionalisme auditor internal terhadap kinerja perusahaan.

$\mathrm{H} 2$ : Kualitas audit terhadap kinerja perusahaan.

H3 : Sistem pengendalian internal terhadap kinerja perusahaan.

\section{METODE PENELITIAN Jenis dan Sumber Data}

Jenis penelitian yang digunakan dalam penelitian ini adalah penelitian asosiatif. Penelitian asosiatif adalah suatu penelitian yang mencari hubungan antara satu variabel dengan variabel yang lain. Hubungan antara variabel ada tiga bentuk, yaitu; simetris, kausal, dan interaktif (Sugiyono, 2016:37). Hubungan yang digunakan dalam penelitian 
ini adalah hubungan kausal. Dimana hubungan kausal adalah hubungan yang bersifat sebab akibat dimana ada variabel independen (variabel yang mempengaruhi) dan variabel dependen (variabel yang dipengaruhi).

\section{Populasi dan Sample}

Populasi dalam penelitian ini adalah seluruh karyawan yang bekerja di Perusahaan Daerah Air Minum (PDAM) Giri Menang Mataram. Adapun kriteria sampel pada penelitian ini adalah :

1. Merupakan pegawai dari PDAM Giri Menang Mataram.

2. Telah bekerja di PDAM Giri Menang Mataram minimal 1 tahun kerja.

3. Merupakan pegawai aktif di PDAM Giri Menang Mataram.

Data Responden

\begin{tabular}{|c|c|c|}
\hline No & Jabatan & Jumlah Responden \\
\hline 1. & Manajer & 13 \\
\hline 2. & Karyawan tetap & 37 \\
\hline \multicolumn{2}{|c|}{ Jumlah } & $\mathbf{5 0}$ \\
\hline
\end{tabular}

\section{Klarifikasi Variabel}

Berdasarkan pada pokok permasalahan dan hipotesis yang dirumuskan, maka variabel-variabel yang dianalisis dalam penelitian ini adalah:

1. Variabel dependen atau terikat dalam penelitian ini adalah kinerja perusahaan.

2. Variabel independen atau bebas dalam penelitian ini adalah profesionalisme auditor internal, kualitas audit dan sistem pengendalian internal.

\section{Definisi Operasional Variabel \\ Profesionalisme Auditor Internal}

Profesionalisme auditor adalah seorang auditor harus memiliki tingkat keterampilan yang umumnya dimiliki oleh auditor pada umumnya dan harus menggunakan keterampilan tersebut dengan kecermatan dan keseksamaan yang wajar (Ramadika dkk, 2014). Dalam penelitian ini, variabel profesionalisme auditor internal diukur dengan dimensi profesionalisme (Hiro Tugiman, 2001) yaitu :

a. Pengabdian pada profesi

b. Kewajiban sosial

c. Kemandirian

d. Keyakinan terhadap peraturan profesi

e. Hubungan dengan sesama profesi

\section{Kualitas Audit}

Kualitas audit adalah sikap auditor dalam melaksanakan tugasnsya yang tercermin dalam hasil pemeriksaannya yang dapat diandalkan sesuai dengan standar yang berlaku. Indikator pengukuran kualitas audit internal ialah :

a. Standar pelaksanaan audit (perencanaan, pengumpulan dan pengujian bukti, pengembangan temuan dan dokumentas).

b. Standar Pelaporan (kewajiban membuat laporan, cara dan saat pelaporan, bentuk dan isi laporan, kualitas laporan, tanggapan auditi serta penerbitan dan distribusi laporan).

\section{Sistem Pengendalian Internal}

Menurut Ratu dan Haryono (2018) pengendalian internal merupakan cara manajeman untuk mengelola transaksi bisni dan aktivitas bisnis secara terkendali dengan tujuan melindungi aset, menghasilkan informasi yang handal, dipatuhinya peraturan perusahaan, dan peraturan pemerintah, serta menghasilkan efektivitas dan efisiensi operasi. 


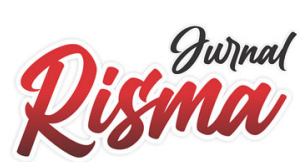

Vol. 1 No. 3 September 2021

\section{Kinerja Perusahaan}

Kinerja perusahaan adalah suatu tampilan keadaan secara utuh atas perusahaan selama periode waktu tertentu, merupakan hasil atau prestasi yang dipengaruhi oleh kegiatan operasional perusahaan dalam memanfaatkan sumber daya-sumber daya yang dimiliki. Kinerja merupakan suatu istilah secara umum yang digunakan untuk sebagian atau seluruh tindakan atau aktivitas dari suatu organisasi pada suatu periode dengan referensi pada jumlah standar seperti biayabiaya masa lalu atau yang diproyeksikan, dengan dasar efisiensi, pertanggungjawaban atau akuntabilitas manajemen dan semacamnya (Srimindarti, 2004).

\section{Prosedur Analisis Data}

\section{Uji Statistik Deskriptif}

Statistik deskriptif menunjukkan gambaran pokok kondisi masing-masing variabel dalam penelitian. Penelitian ini menggunakan parameter jumlah jawaban dari responden yang menjawab sangat setuju, setuju, kurang setuju, tidak setuju dan sangat tidak setuju pada tiap-tiap indikator pernyataan dalam kuesioner.

\section{Uji Validitas dan Reliabilitas Data}

Uji validitas digunakan untuk mengukur sah atau valid tidaknya suatu kuesioner. Suatu kuesioner dikatakan sah atau valid jka pertanyaan pada suatu kuesioner mampu mengungkapkan sesuatu yang akan diukur oleh kuesioner tersebut. Untuk melakukan uji validitas dapat dilakukan uji signifikasi yaitu dengan membandingkan nilai $r$ hitung (nilai corrected item total correlation pada output CronbachAlpha) dengan $\mathrm{r}$ tabel untuk degreeoffreedom $(\mathrm{df})=\mathrm{n}-2$, dengan alpha 0,05 . Jika $\mathrm{r}$ hitung lebih besar dari pada $\mathrm{r}$ tabel maka butir pertanyaan tersebut dapat dinyatakan valid.Sedangakan uji reliabilitas adalah sebuah alat ukur untuk mengukur suatu kuesioner yang merupakan indikator dari variabel atau konstruk. Suatu kuesioner dikatakan reliabel atau handal jika jawaban seseorang terhadap pertanyaan yang diajukan adalah konsisten atau stabil dari waktu ke waktu. Pengukuran reliabilitas dapat dilakukan dengan uji statistik Cronbach Alpha. Suatu variabel dikatakan reliabel apabila memberikan nilai CronbachAlpha $>0.60$.

\section{Uji Normalitas}

Uji normalitas dimaksudkan untuk menguji apakah nilai residual yang telah terstandarisasi pada model regresi berdistribusi normal atau tidak. Nilai residual dikatakan berdistribusi normal jika nilai residual terstandarisasi tersebut sebagian besar mendekati nilai rata-ratanya.

\section{Uji Multikolinieritas}

Uji Multikolinieritas bertujuan untuk menguji apakah dalam model regresi yang terbentuk ada korelasi yang tinggi atau sempurna di antara variabel bebas. Multikolinieritas adalah hubungan liniear antar variabel independen di dalam regresi berganda. Model regresi yang baik seharusnya tidak terjadi korelasi di antara variabel independen.

\section{Uji Heteroskedastisitas}

Uji heteroskedastisitas bertujuan untuk menguji apakah dalam model regresi yang terbentuk terjadi ketidaksamaan varian dari residual model regresi. Adapun untuk mendeteksi ada tidaknya heteroskedastisitas dengan melihat grafik plot antara nilai prediksi variable dependent dengan residualnya. 


\section{Pengujian Hipotesis}

Analisis regresi berganda digunakan untuk menguji pengaruh variabel independen terhadap variabel dependen. Model regresi yang dikembangkan untuk menguji hipotesis-hipotesis yang telah dirumuskan dalam penelitian ini adalah :

$$
\mathrm{Y}=\alpha+\mathrm{b}_{1} \mathrm{X}_{1}+\mathrm{b}_{2} \mathrm{X}_{2}+\mathrm{b}_{3} \mathrm{X}_{3}+\mathrm{e}
$$

Keterangan :

$\begin{array}{ll}\alpha & : \text { Konstanta } \\ \mathrm{b}_{1}, \mathrm{~b}_{2}, \mathrm{~b}_{3}, & : \text { Koefisien Variabel } \\ \mathrm{x} 1 & : \text { Profesionalisme Auditor Internal } \\ \mathrm{x} 2 & : \text { Kualitas Audit Internal } \\ \mathrm{x} 3 & : \text { Sistem Pengendalian Internal } \\ \mathrm{x} 4 & : \text { Resiko Audit } \\ \mathrm{e} & : \text { error }\end{array}$

Terdapat beberapa tahapan tahapan dalam melakukan uji hipotesis regresi, tahapan tersebut antara lain:

1. Uji F

Uji statistik F pada dasarnya menunjukkan apakah semua variabel independen atau bebas yang dimasukkan dalam model mempunyai pengaruh secara bersama-sama terhadap variabel dependen/terikat.

2. Uji Koefisien Determinan $\left(\mathrm{R}^{2}\right)$

Koefisien determinan $\left(\mathrm{R}^{2}\right)$ pada intinya mengukur seberapa jauh kemampuan model dalam menerangkan variasi variabel dependen. Dalam persamaan regresi yang digunakan lebih dari satu variabel independen, maka nilai $\mathrm{R}^{2}$ yang baik digunakan untuk menjelaskan persamaan regresi adalah koefisien determinasi yang disesuaikan karena Adjusted $R$ Square dapat naik atau turun apabila satu variabel independen ditambahkan ke dalam model (Ghozali, 2007).

3. Uji Statistik $t$

Uji t (uji parsial) digunakan untuk melihat signifikasi dari pengaruh independen secara individu terhadap variabel dependen dengan menganggap variabel lain bersifat konstan. Nilai t hitung digunakan untuk menguji apakah sebuah variabel bebas berpengaruh secara signifikan terhadap variabel tergantung atau tidak. Pengujian ini dilakukan dengan cara memperbandingkan $t$ hitung dengan $t$ tabel.

\section{HASIL DAN PEMBAHASAN \\ Gambaran Penelitian}

Kuesioner yang disebarkan berjumlah 50 kuisioner. Jumlah kuesioner yang kembali sejumlah 50 kuisioner atau 100\%, sedangkan kuisioner yang tidak kembali tidak ada atau 0 . Kuisioner yang dapat diolah berjumlah 50 kuesioner atau $100 \%$ dapat diolah semua karena memenuhi kriteria sebagai sampel.

Data Sampel Penelitian

\begin{tabular}{|c|l|c|c|}
\hline No & \multicolumn{1}{|c|}{ Keterangan } & Jumlah & Persentase \\
\hline 1 & Jumlah kuesioner yang disebar & 50 & $100 \%$ \\
\hline 2 & Jumlah kuesioner yang tidak kembali & 0 & $0 \%$ \\
\hline 3 & Jumlah kuesioner yang kembali & 50 & $100 \%$ \\
\hline 4 & Jumlah kuesioner yang dapat diolah & 50 & $100 \%$ \\
\hline 5 & Jumlah kuesioner yang tidak dapat diolah & 0 & $0 \%$ \\
\hline
\end{tabular}




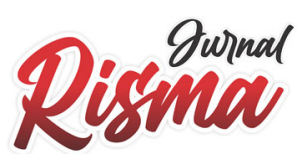

Vol. 1 No. 3 September 2021

\section{Analisis Statistik Deskriptif}

Sumber: Data primer diolah, 2020

\section{Analisis Statistik Deskriptif Variabel Profesionalisme Auditor Internal}

Sesuai dengan hasil analisis pada variable profesionalisme auditor internal terlihat bahwa dari pertanyaan 1 sampai 5, rata-rata responden menjawab dengan jawaban setuju dan sangat setuju dengan profesionalisme auditor internal dapat dilihat persentase sebesar 89,2 \%. Dari hasil statistik deskriptif terlihat bahwa auditor yang bekerja di perusahaan PDAM Giri Menang Mataram juga sudah melakukan tugasnya dengan baik. Artinya ratarata dari 50 responden mempunyai presepsi setuju terhadap pernyataan bahwa auditor internal terhadap pengabdian pada profesi, kewajiban social, kemandirian, keyakinan terhadap peraturan dan hubungan sesame profesi.

\section{Analisis Statistik Deskriptif Variabel Kualitas Audit}

Berdasarkan analisis yang digunakan dapat dilihat bahwa sebesar $82 \%$ responden setuju dan sangat setuju dengan kualitas audit dan sebanyak $18 \%$ responden yang masih kurang setuju dan tidak setuju dengan kualitas audit di perusahaan PDAM Giri Menang Mataram. Dimana bermakna sejumlah 50 responden setuju untuk kualitas audit yang bekerja di perusahaan PDAM Giri Menang Mataram sudah baik yang mana tata cara pelaksanaan audit sudah sesuai standar begitu juga dengan penerbitan laporan hasil auditnya.

\section{Analisis Statistik Deskriptif Variabel Sistem Pengendalian Internal}

Dalam analisi ini dapat dilihat persentase sebesar 90\% sangat setuju dan setuju dengan kinerja perusahaan dan sebanyak 10\% kurang setuju dan tidak setuju dengan kinerja perusahaan. Dari data statistik deskriptif diatas dapat dilihat bahwa kinerja perusahaan pada perusahaan PDAM Giri Menang sudah baik. Dimana responden setuju untuk kinerja perusahaan pada perusahaan PDAM Giri Menang Mataram yang dikategorikan dalam kepuasan stakeholder, strategi, proses, kemampuan, dan kontribusi stakeholder sudah baik dan sesuai dengan standar yang ada.

\section{Analisis Statistik Deskriptif Variabel Kinerja Perusahaan}

Berdasarkan analisis variabel untuk kinerja perusahaan dapat dilihat persentase sebesar $90 \%$ sangat setuju dan setuju dengan kinerja perusahaan dan sebanyak $10 \%$ kurang setuju dan tidak setuju dengan kinerja perusahaan. Dari data statistik deskriptif diatas dapat dilihat bahwa kinerja perusahaan pada perusahaan PDAM Giri Menang sudah baik. Dimana responden setuju untuk kinerja perusahaan pada perusahaan PDAM Giri Menang Mataram yang dikategorikan dalam kepuasan stakeholder, strategi, proses, kemampuan, dan kontribusi stakeholder sudah baik dan sesuai dengan standar yang ada. Uji Validitas

Dari hasil pengujian validitas dapat diketahui bahwa pernyataan yang terdapat dalam kuesioner mengenai profesionalisme auditor internal, kualitas audit, sistem pengendalian internal dan kinerja perusahaan memiliki r-hitung lebih besar dari r-tabel yang sebesar 0,3712. Oleh karena itu pernyataan dalam kuesioner mengenai profesionalisme auditor internal, kualitas audit, sistem pengendalian internal dan kinerja perusahaan yang terdapat dalam kuesioner dapat dikatakan valid dan dapat dilakukan pengujian pada tahap selanjutnya.

\section{Uji Reabilitas}

\begin{tabular}{|l|c|c|c|}
\hline \multicolumn{1}{|c|}{ Variabel } & $\begin{array}{c}\text { Koefisien } \\
\text { Cronbach's Alpha }\end{array}$ & $\begin{array}{c}\text { Nilai } \\
\text { Kritis }\end{array}$ & Keterangan \\
\hline $\begin{array}{l}\text { Profesionalisme Auditor } \\
\text { Internal }\end{array}$ & 0,870 & 0,6 & Reliabel \\
\hline
\end{tabular}




\begin{tabular}{|l|c|c|c|}
\hline \multicolumn{1}{|c|}{ Variabel } & $\begin{array}{c}\text { Koefisien } \\
\text { Cronbach's Alpha }\end{array}$ & $\begin{array}{c}\text { Nilai } \\
\text { Kritis }\end{array}$ & Keterangan \\
\hline Kualitas Audit & 0,833 & 0,6 & Reliabel \\
\hline $\begin{array}{l}\text { Sistem Pengendalian } \\
\text { Internal }\end{array}$ & 0,972 & 0,6 & Reliabel \\
\hline Kinerja Perusahaan & 0,969 & 0,6 & Reliabel \\
\hline
\end{tabular}

Sumber: Lampiran 5

Dari tabel diatas dapat diketahui hasil pengujian reliabilitas untuk instrumen yang ada dalam kuesioner mengenai profesionalisme auditor internal, kualitas audit, sistem pengendalian internal dan kinerja perusahaan memiliki nilai Cronbach Alpha ( $\alpha$ ) yang lebih besar dari 0,6. Dengan demikian item-item pernyataan dalam kuesioner mengenai profesionalisme auditor internal, kualitas audit, sistem pengendalian internal dan kinerja perusahaan yakni reliable atau andal. Hal ini menunjukkan bahwa setiap item pertanyaan yang digunakan akan mampu memperoleh data yang konsisten yang berarti bila pertanyaan itu diajukan kembali akan diperoleh jawaban yang relatif sama dengan jawaban sebelumnya.

\section{Uji Normalitas}

\begin{tabular}{|ll|r|}
\hline \multicolumn{2}{|c|}{ One-Sample Kolmogorov-Smirnov Test } \\
\hline & & Unstandardized Residual \\
\hline Normal Parameters & 39 \\
& Mean &, 0000000 \\
Most Extreme Differences & Std. Deviation & 2,09964141 \\
& Posolute & 117 \\
& Positive &, 117 \\
Test Statistic & Negative &,- 062 \\
Asymp. Sig. (2-tailed) & &, 117 \\
\hline
\end{tabular}

a. Test distribution is Normal.

b. Calculated from data.

c. Lilliefors Significance Correction.

Sumber: Lampiran 5

Menurut tabel di atas, hasil uji Kolmogorov-smirnov menunjukkan bahwa data yang terdistribusi normal. Hal ini terlihat dari nilai probabilitas signifikansi sebesar $0,195>0,05$ sehingga model penelitian ini memenuhi uji asumsi klasik normalitas.

\section{Uji Multikolinearitas}

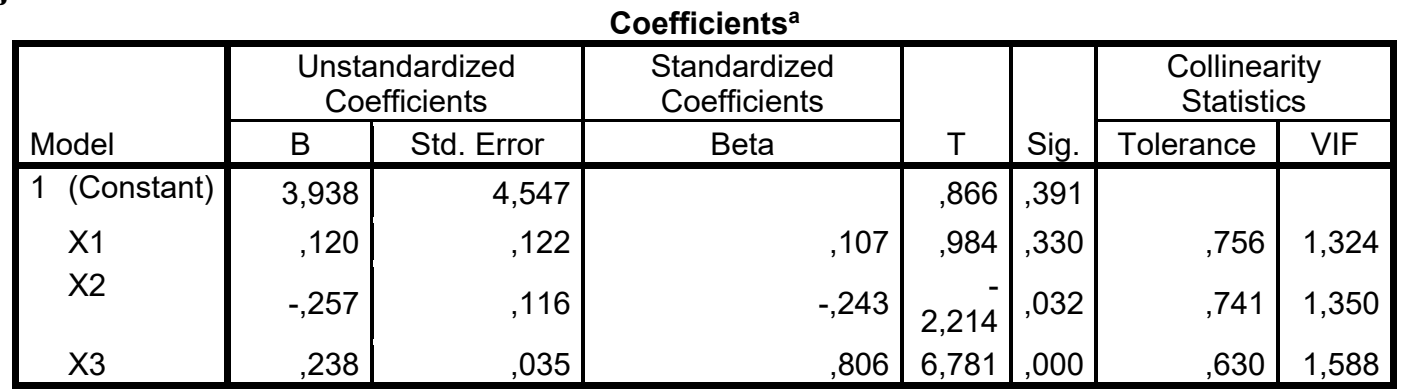

a. Dependent Variable: $Y$

Sumber: Lampiran 5

Berdasarkan tabel di atas terlihat nilai tolerance $>0,1$ dan nilai VIF $<10$ untuk setiap variabel, yang ditunjukkan dengan nilai tolerance untuk profesionalisme auditor internal(X1) sebesar 0,756, kualitas audit (X2) sebesar 0,741, sistem pengendalian internal (X3) sebesar 0,630. Dengan nilai VIF untuk profesionalisme auditor internal (X1) sebesar 1,324, kualitas audit (X2) sebesar 1,350, sistem pengendalian internal (X3) 
sebesar 1,588. Dengan demikian dapat disimpulkan bahwa model persamaan regresi tidak terdapat multikolinearitas atau tidak ada hubungan antara dua variabel bebas atau lebih dalam sebuah model regresi.

\section{Uji Heteroskedastisitas}

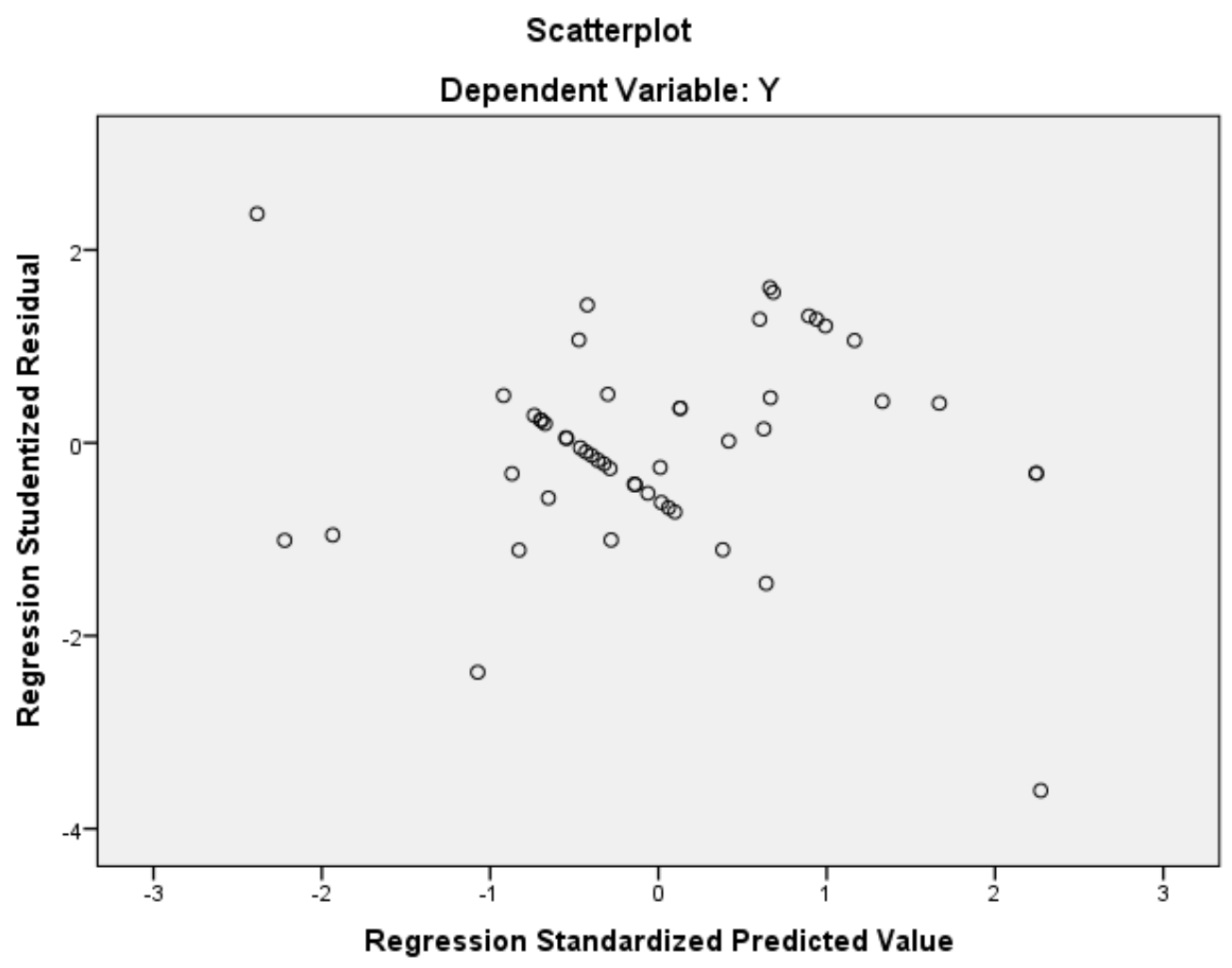

Sumber: Lampiran 5

Berdasarkan gambar grafik scatterplot menunjukkan bahwa data tersebut di atas dan di bawah angka 0 (nol) pada sumbu Y dan tidak terdapat suatu pola yang jelas pada penyebaran data tersebut. Ini menandakan bahwa tidak terjadi heteroskedastisitas. Berikut hasil uji heteroskedastisitas menggunakan uji glejser.

\section{Coefficients $^{\mathrm{a}}$}

\begin{tabular}{|c|c|c|c|c|c|}
\hline \multirow[b]{2}{*}{ Model } & \multicolumn{2}{|c|}{$\begin{array}{c}\text { Unstandardized } \\
\text { Coefficients }\end{array}$} & \multirow{2}{*}{$\begin{array}{c}\text { Standardized } \\
\text { Coefficients } \\
\text { Beta }\end{array}$} & \multirow[b]{2}{*}{$\mathrm{T}$} & \multirow[b]{2}{*}{ Sig. } \\
\hline & $\mathrm{B}$ & Std. Error & & & \\
\hline 1 (Constant) & 3,507 & 2,940 & & 1,193 & ,239 \\
\hline X1 &,- 120 & ,079 &,- 249 & $1,530^{-}$ & 133, \\
\hline X2 &,- 079 & ,075 &,- 174 & 1,060 & ,295 \\
\hline X3 & ,037 & ,023 & ,289 & 1,625 & 111 \\
\hline
\end{tabular}

a. Dependent Variable: Abs_Res

Sumber: Lampiran 5

Berdasarkan tabel di atas menunjukkan nilai signifikansi variabel profesionalisme auditor internal sebesar 0,133 , kualitas audit 0,295, sistem pengendalian internal 0,111 lebih dari 0,05 maka dapat disimpulkan bahwa tidak terjadi gejala heteroskedastisitas atau penyimpangan dari model regresi. 


\section{Analisis Regresi Berganda}

\begin{tabular}{|c|c|c|c|c|c|}
\hline \multirow[b]{2}{*}{ Model } & \multicolumn{2}{|c|}{ Unstandardized Coefficients } & \multirow{2}{*}{$\frac{\text { Standardized Coefficients }}{\text { Beta }}$} & \multirow[b]{2}{*}{$\mathrm{T}$} & \multirow[b]{2}{*}{ Sig. } \\
\hline & $\mathrm{B}$ & Std. Error & & & \\
\hline 1 (Constant) & 3,938 & 4,547 & & ,866 & ,391 \\
\hline $\mathrm{X} 1$ & ,120 & ,122 & , 107 & ,984 & ,330 \\
\hline $\mathrm{X} 2$ &,- 257 & ,116 &,- 243 & $-2,214$ & ,032 \\
\hline X3 & ,238 & ,035 & ,806 & 6,781 &, 000 \\
\hline
\end{tabular}

a. Dependent Variable: $Y$

\section{Sumber: Lampiran 5}

Berdasarkan tabel di atas, maka model persamaan regresi linear berganda yang dapat disusun sebagai berikut:

$$
\mathrm{Y}=3,938+0,120 \mathrm{X} 1-0,257 \mathrm{X} 2+0,238 \times 3+e
$$

Konstanta sebesar 3,938 pada persamaan regresi linear berganda tersebut dapat diartikan bahwa apabila variabel independen (profesionalisme auditor internal, kualitaas audit dan sistem pengendalian internal) dianggap konstan atau bernilai nol, maka nilai kinerja perusahaan sampel adalah sebesar 3,938.

Pada tabel dapat dilihat bahwa koefisien variabel profesionalisme auditor internal sebesar 0,120 . Hal ini menunjukkan bahwa variabel profesionalisme auditor internal mengalami peningkatan sebesar satu satuan nilai, maka nilai variabel kinerja perusahaan akan mengalami kenaikan sebesar 0,120. Dengan asumsi variabel lain dalam keadaan konstan. Nilai koefisien yang positif menandakan jika profesionalisme auditor internal meningkat maka tingkat kinerja perusahaan juga akan mengalami peningkatan.

Koefisien variabel kualitas audit sebesar -0,257 menunjukkan bahwa apabila nilai kualitas audit mengalami penurunan sebesar satu satuan nilai maka nilai kinerja perusahaan mengalami penurunan sebesar -0,257 dengan asumsi variabel lain dalam keadaan konstan. Nilai negatif pada koefisien variabel kualitas audit menunjukkan adanya hubungan yang sejalan dimana jika kualitan audit mengalami penurunan maka kinerja perusahaan juga akan mengalami penurunan.

Koefisien variabel sistem pengendalian internal sebesar 0,238 menunjukan bahwa apabila nilai sistem pengendalian internal mengalami peningkatan sebesar satu satuan nilai maka nilai kinerja perusahaan akan mengalami peningkatan sebesar 0,238 dengan asumsi variabel lain dalam keadaan konstan. Nilai positif pada koefisien variabel sistem pengendalian internal menunjukkan adanya hubungan yang berkaitan dimana jika sistem pengendalian internal meningkat maka kinerja perusahaan akan mengalami pingkatan juga.

Dalam pengujian regresi linear berganda ada beberapa uji yang digunakan dalam penelitian ini yaitu:

\section{Uji Signifikansi Simultan (Uji Statistik F)}

\begin{tabular}{|l|r|r|r|r|l|}
\hline Model & \multicolumn{1}{|c|}{$\begin{array}{c}\text { Sum of } \\
\text { Squares }\end{array}$} & df & $\begin{array}{c}\text { Mean } \\
\text { Square }\end{array}$ & F & Sig. \\
\hline 1 Regression & 499,624 & 3 & 166,541 & 22,131 &, $000^{\mathrm{b}}$ \\
Residual & 346,156 & 46 & 7,525 & & \\
Total & 845,780 & 49 & & & \\
\hline
\end{tabular}
a. Dependent Variable: $\mathrm{Y}$
b. Predictors: (Constant), X3, X1, X2

Sumber : Lampiran 5 
Tabel di atas menunjukkan nilai $\mathrm{F}$ hitung sebesar 22,131 dengan tingkat signifikansi 0,000. Karena probabilitas signifikansi jauh lebih kecil dari 0,05 maka model regresi dapat digunakan untuk memprediksi profesionalisme auditor internal, kualitas auditor, sistem pengendalian internal secara bersama-sama berpengaruh terhadap kinerrja perusahaan.

\section{Uji Koefisien Determinan $\left(\mathbf{R}^{2}\right)$}

Model Summary

Sumber

\begin{tabular}{|l|c|r|r|r|}
\hline Model & $\mathrm{R}$ & $\mathrm{R}$ Square & Adjusted R Square & Std. Error of the Estimate \\
\hline 1 &, $769^{\mathrm{a}}$ &, 591 &, 564 & 2,74320 \\
\hline
\end{tabular}

a. Predictors: (Constant), X3, X1, X2

Lampiran 5

Tabel diatas menunjukkan bahwa nilai Adjusted R square sebesar 0,564. Hal ini menandakan bahwa variasi variabel profesionalisme auditor internal, kualitas audit, dan sistem pengendalian internal mampu menjelaskan $100 \%$ variasi variabel kinerja perusahaan.

\section{Uji Parsial (Uji t)}

Coefficients $^{a}$

\begin{tabular}{|c|c|c|c|c|c|}
\hline \multirow[b]{2}{*}{ Model } & \multicolumn{2}{|c|}{ Unstandardized Coefficients } & \multirow{2}{*}{$\begin{array}{c}\begin{array}{c}\text { Standardized } \\
\text { Coefficients }\end{array} \\
\text { Beta }\end{array}$} & \multirow[b]{2}{*}{$\mathrm{t}$} & \multirow[b]{2}{*}{ Sig. } \\
\hline & $B$ & Std. Error & & & \\
\hline '(Constant) & 3,938 & 4,547 & & ,866 & ,391 \\
\hline $\mathrm{X} 1$ & 120 & , 122 & , 107 & ,984 & ,330 \\
\hline $\mathrm{X} 2$ &,- 257 & 116 &,- 243 & $-2,214$ & ,032 \\
\hline X3 & ,238 & ,035 & ,806 & 6,781 & ,000 \\
\hline
\end{tabular}

a. Dependent Variable: $Y$

Sumber: Lampiran 5

Hasil pengujian signifikansi variabel bebas secara parsial dapat dilihat pada pembahasan sebagai berikut :

Hasil uji t untuk profesionalisme auditor interrnal(X1) diperoleh t hitung sebesar 0,984 yang artinya lebih kecil dari t tabel yaitu 2,012 serta mempunyai signifikansi sebesar 0,330 lebih besar dari 0,05. Hal ini menunjukkan bahwa profesionalisme auditor internal tidak memiliki pengaruh yang signifikan, dengan demikian H1 ditolak.

1. Hasil uji t untuk variabel kualitas audit(X2) diperoleh $t$ hitung sebesar -2,2214 yang artinya lebih kecil dari t tabel yaitu 2,012 serta mempunyai signifikansi sebesar 0,032 lebih kecil dari 0,05. Hal ini menunjukkan bahwa kualitas audit memiliki pengaruh yang signifikan terhadap kinerja perusahaan (Y), dengan demikian $\mathrm{H} 2$ diterima.

2. Hasil uji t untuk variabel sistem pengendalian internal(X3) diperoleh thitung sebesar 6,781 yang artinya lebih besar dari t tabel yaitu 2,012 serta mempunyai signifikansi sebesar 0,000 lebih kecil dari 0,05. Hal ini menunjukkan bahwa sistem pengendalian internal memiliki pengaruh yang signifikan terhadap kinerja perusahaan (Y), dengan demikian $\mathrm{H} 3$ diterima.

\section{Interpretasi Hasil Penelitian}

\section{Pengaruh Profesionalisme Auditor Internal terhadap Kinerja Perusahaan}

Hasil pengujian $t$ menghasilkan koefisien regresi dari variabel profesionalisme auditor internal sebesar $-0,044$ dan nilai t-hitung sebesar $-0,310$ dengan tingkat signifikansi yang dihasilkan 0,758 yang menunjukkan bahwa nilai signifikansinya lebih besar dari tingkat signifikansi yang ditentukan yaitu 0,05 . Sehingga hal ini tidak sejalan 
dengan hipotesis penelitian, dimana hasil penelitian ini membuktikan bahwa profesionalisme auditor internal tidak mempunyai pengaruh terhadap kinerja perusahaan, artinya profesionalisme auditor internal memiliki pengaruh yang lemah dilihat dari nilai signifikansinya. Dengan demikian hipotesis yang menyatakan profesionalisme auditor internal berpengaruh terhadap kinerja perusahaan ditolak (H1 ditolak). Berdasarkan penelitian Ramadika dkk (2014) profesionalisme auditor diartikan seorang auditor harus memiliki tingkat keterampilan yang umumnya dimiliki oleh auditor dan harus menggunakan keterampilan tersebut dengan kecermatan dan keseksamaan yang wajar (Ramadika dkk, 2014). Sehingga tidak berpengaruhnya hipotesis pertama pada penelitian ini bisa terjadi karena kurangnya rasa percaya diri atau tingkat keterampilan profesional auditor akan pentingnya pekerjaan disebabkan kurangnya hubungan dengan rekan seprofesi sehingga kurang bisa membangun kesadaran profesional.

Hasil ini tidak sejalan dengan penelitian Pernilla (2013) yang melakukan penelitian tentangAuditors Professional and organisational identities and perceived commercialisation in audit firm. Hasil dari penelitian ini menunjukkan bahwa profesionalisme audit internal berpengaruh terhadap kinerja perusahaan.

\section{Pengaruh Kualitas Audit terhadap Kinerja Perusahaan}

Hasil dari uji t variabel kualitas audit menghasilkan koefisien regresi sebesar 0,500 dan t-hitung sebesar -3,247 dengan tingkat signifikansi yang dihasilkkan yaitu 0,003 yang menunjukkan bahwa tingkat signifikansinya lebih rendah dari tingkat signifikansi yang ditentukan yaitu 0,05. Sehingga dapat ditarik kesimpulan bahwa kualitas audit berpengaruh terhadap kinerja perusahaan atau dengan kata lain $\mathrm{H} 2$ diterima. Penelitian ini juga menemukan bahwa adanya presepsi berbeda oleh karyawan terhadap kualitas audit yang berada di perusahaan PDAM Giri Menang Mataram. Kualitas audit diartikan sebagai sikap auditor dalam melaksanakan tugasnya yang tercermin dalam hasil pemeriksaannya yang dapat diandalkan sesuai dengan standar yang berlaku. Sehingga hipotesis ini juga diartikan bahwa auditor dengan mudah mengikuti prosedur audit dengan baik, sehingga auditor dapat medeteksi salah saji dan material perusahaan PDAM Giri Menang Mataram dengan mudah dan dapat dipertanggungjawabkan, yang berarti dalam penelitian ini kualitas audit berpengaruh terhadap kinerja perusahaan. Dimana bila audit dilakukan secara berkualitas dan sesuai dengan standar yang ada, maka laporan audit yang dihasilkan akan layak untuk dijadikan acuan dalam menilai kinerja perusahaan. Saat pelaksanaan audit didapatkan hasil yang baik, maka bisa dikatakan kinerja perusahaan baik juga. Kualitas audit suatu perusahaan juga sangat penting bukan hanya untuk kelancaran dalam perusahaan tetapi juga bagi pihak luar perusahaan semakin baik atau bagus maka kinerja perusahaan juga akan meningkat.

Hasil ini sejalan dengan penelitian yang telah diajukan sebelumnya oleh Suzanne dan Bijkerk (2018) yang menjelaskan bahwa kualitas audit memiliki pengaruh terhadap kinerja perusahaan, dimana hasil penelitiannya meunjukkan bahwa kualitas audit berpengaruh terhadap kualitas audit. Penelitian Dewi (2007) yang berjudul pengaruh kualitas audit internal dan peluang pertumbuhan terhadap kinerja perusahaan dengan independensi komite audit sebagai variabel moderasinya, mempunyai hasil bahwa kualitas audit berpengaruh namun tidak signifikan terehadap kinerja perusahaan, dengan nilai signifikansi hitung sebesar $0,782>0,05$. Tetapi hal ini tidak sejalan dengan penelitian dari H.Sayyer (2015), Suzanne dan Bijkerk (2018) yang menjelaskan bahwa kualitas audit memiliki pengaruh terhadap kinerja perusahaan. 


\section{Pengaruh Sistem Pengendalian Internal terhadap Kinerja Perusahaan}

Hasil uji t menghasilkan koefisien regrresi sebesar 1,619 dan nilai t-hitung sebesar 9,600 dengan tingkat signifikansi sebesar 0,000 yang menunjukkan bahwa nilai signifikansinya lebih kecil dari nilai signifikansi yang ditentukan yaitu 0,05. Sehingga dapat disimpulkan bahwa sistem pengendalian internal berpengaruh terhadap kinerja perusahaan atau $\mathrm{H} 3$ diterima.

Salah satu masalah yang mengharuskan perusahaan mempunyai suatu sistem pengendalian internal yaitu berawal dari sering dijumpai adanya penyimpangan yang dilakukan karyawan serta ketidakefisienan pelaksanaan kinerja. Pengendalian intern sendiri bertujuan mengurangi bahkan menghilangkan resiko terjadinya penyimpangan yang berhubungan dengan tindakan-tindakan yang diambil dalam suatu organisasi untuk membantu mengatur dan mengarahkan aktivitas organsiasi. Dengan adanya pengendalian intern dapat menuntut semua karyawan untuk menjalankan tanggung jawab secara efektif. Semakin baik sistem pengendalian internal yang diterapkan dalam perusahaan maka kinerja perusahaan PDAM Giri Menang Mataram juga akan semakin baik.

Hasil penelitian ini sejalan dengan Zulkarnain (2013), hasil analisis menunjukkan bahwa terdapat pengaruh yang signifikan dari sistem pengendalian internal terhadap kinerja perusahaan. Semakin baik sistem pengendalian internal yang diterapkan dalam perusahaan maka kinerja perusahaan akan semakin baik. Penelitian Benson Mugi Benson Mugi (2018) juga menunjukkan bahwa sistem pengendalian internal memiliki pengaruh terhadap kinerja perusahaan. Hal yang sama juga dibuktikan oleh Hassan (2016) dengan judul tentang Effects Of Internal Control System On The Organizatoinal Performance Of Remittance Companies In Modadishu-Somaliamenunjukkan hasil bahwa sistem pengendalian internal berpengaruh terhadap kinerja perusahaan. 


\section{SIMPULAN, KETERBATASAN DAN SARAN SERTA IMPLIKASI PENELITIAN \\ Simpulan}

Hasil penelitian ini membuktikan bahwa profesionalisme auditor internal tidak memiliki pengaruh terhadap kinerja perusahaan. Artinya bahwa profesionalisme auditor tidak berpengaruh terjadi karena kurangnya rasa percaya diri atau tingkat keterampilan profesional auditor akan pentingnya pekerjaan disebabkan kurangnya hubungan dengan rekan seprofesi sehingga kurang bisa membangun kesadaran profesional.Sehingga tidak berpengaruhnya profesionalisme auditor internal terhadap kinerja perusahaan terjadi karena kurangnya rasa percaya diri atau tingkat keterampilan profesional auditor akan pentingnya pekerjaan disebabkan kurangnya hubungan dengan rekan seprofesi sehingga kurang bisa membangun kesadaran profesional.

Hasil penelitian ini membuktikan bahwa kualitas audit berpengaruh terhadap kinerja perusahaan. Artinya bahwa audiitor dengan mudah mengikuti prosedur audit dengan baik, sehingga auditor dapat medeteksi salah saji dan material perusahaan PDAM Giri Menang Mataram dengan mudah dan dapat dipertanggungjawabkan. Dimana bila audit dilakukan secara berkualitas dan sesuai dengan standar yang ada, maka laporan audit yang dihasilkan akan layak untuk dijadikan acuan dalam menilai kinerja perusahaan. Saat pelaksanaan audit didapatkan hasil yang baik, maka bisa dikatakan kinerja perusahaan baik juga.

Sistem pengendalian internal berpengaruh terhadap kinerja perusahaan. Sehingga dapat disimpulkan bahwa sistem pengendalian internal berpengaruh terhadap kinerja perusahaan atau H3 diterima. Dengan adanya pengendalian intern dapat menuntut semua karyawan untuk menjalankan tanggung jawab secara efektif.Pengendalian intern sendiri bertujuan mengurangi bahkan menghilangkan resiko terjadinya penyimpangan yang berhubungan dengan tindakan-tindakan yang diambil dalam suatu organisasi untuk membantu mengatur dan mengarahkan aktivitas organsiasi. Selain itu komunikasi informasi dan pemantauan tetap harus dijalankan agar sistem pengendalian internal berjalan dengan baik dan konsisten.

\section{Saran}

1. Jika tujuan penelitian untuk mendapatkan hasil yang lebih relevan disarankan untuk menambah jumlah responden. Dengan memperbanyak responden akan memperkuat hasil penelitian tersebut.

2. Untuk penelitian selanjutkan disarankan untuk menambah variabel independen lainnya yang mempengaruhi kinerja perusahaan.

3. Diharapkan pada penelitian selanjutnya akan lebih banyak memuat penelitian terdahulu untuk menguatkan penelitiannya. Karena penelitian tersebut tidak merata terhadap variabel yang digunakan, sehingga kedepannya diharapkan penelitian selanjutnya menggunakan variabel yang lebih bervariasi agar dimaksudkan mendapat hasil yang baru. 


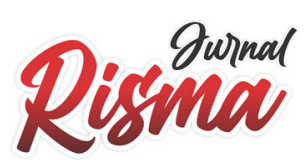

Vol. 1 No. 3 September 2021

\section{DAFTAR PUSTAKA}

Agoes, Sukrisno. 2012. Auditing (Petunjuk Praktis Pemeriksaan Akuntan oleh Kantor Akuntan Publik). Edisi 4. Buku 1. Jakarta: Salemba Empat.

Agoes, Sukrisno. 2017. Auditing ( Petunjuk Praktis Pemeriksaan Akuntan oleh Akuntan Publik). Edisi 5. Buku 1. Jakarta: Salemba Empat.

Anandi tatiana, Ratu Agi. Haryono Umar. 2018. Pengendalian Internal dan audit Internal terhadap Kinerja Penjualan Perusahaan (Studi pada PT.B\&K Baja Utama). Volume 2, No. 1, Januari 2018.

Aprilia, Nanda Rizky. Mohammad Rafki Nazar. Djusnimar Zultilisna. 2017. Pengaruh Audit Operasional dan Pengendalian Internal terhadap Kinerja Perusahaan (Studi Kasus pada Hotel Inna Bali). Vol. 4, No. 2.

Broberg, Pernilla PhD. Timurs Umans, PhD. Peter Skog, MSc. Emily Theodorsson, MSc. 2013. Auditors' Professional and Organisational Identities and Perceived Commercialisation in Audit Firms.

Christiani, I., \& Nugrahanti, Y. W. (2014). Pengaruh Kualitas Audit Terhadap Manajemen Laba. Jurnal Akuntansi Dan Keuangan, 16(1), 52-62. https://doi.org/10.9744/jak.16.1.52-62

Dahir, Abdulahi Ahmed. Nagib Omar. 2016. Effects of Internal Audit Practice on Organizational Performance of Remittance Companies in ModadishuSomalia.Volume 2.

Datenusa, Dewi Zakiyah. 2017. Pengaruh Kualitas Audit Internal dan Peluang Pertumbuhan terhadap Kinerja Perusahaan dengan Independensi Komite Audit Sebagai Variabel Moderasi.

Elfarini, Eunike Christina. 2007. Pengaruh Kompetensi dan Independensi Auditor terhadap Kualitas Audit. Penelitian. Universitas Negeri Semarang.

Gaspersz, Vincent. 2005. Sistem Manajemen Kinerja Terintegrasi Balanced Scorecarddengan Six Sigma untuk Organisasi Bisnis dan Pemeritah. Jakarta: Gramedia Pustaka Utama.

Hartoyo, Sri. 2017. Buku Kinerja PDAM 2017. Kementerian Pekerjaan Umum dan Perumahan Rakyat. Jakarta.

Hassan PhD, Shehu Usman. Musa Adeiza Farouk. 2014. Audit Quality and Financial Performance of Quote Cement Firms in Nigeria. Vol. 6, No. 28, 2014.

Mire, Hassan Adam. 2016. Effect of Internal Control System On The Organizational Performance of Remittance Companies in Modadishu- Somalia. Volume 2.

Muhunyo, Benson Mugi. 2018. Effect of Internal Control Systems on Financial Performance of Public Institution of Higher Learning In Nairobi City County, Kenya.

Mulyadi. 2009. Akuntansi Biaya. Edisi ke 5. Yogyakarta: STIE YKPN.

Rivai dan Basri. 2004. Manfaat Penilaian Kinerja. Jurnal http://jurnalsdm.blogspot.com/2004/04/penilaian-kinerja-karyawan-definisi.html.

Sayyar, Hamed. R. Basiruddin. S.Z Abdul Rasid. M.A. Elhabib. 2015. The Impact of Audit Quality on Firm Performance: Evidance From Malaysia. Vol. 10, No.1. Pages 1-19.

Seniati, L., Yulianto, A., \& Setiadi, B. N. 2015. Psikologi Eksperimen. Jakarta: Indeks.

Srimindarti, Ceacilia. 2004. Balanced Scorecard sebagai Alternatif untuk Mengukur Kinerja. Fokus Ekonomi. Vol. 3, No. 1, April.

Sugiyono. 2008. Metode Penelitian Kuantitatif Kualitatif dan R\&D. Bandung : Alfabeta. Sugiyono. 2015. Metode Penelitian Kombinasi (Mix Methods). Bandung: Alfabeta. 
Sugiyono. 2016. Metode Penelitian Kuantitatif, Kualitatif dan R\&D. Bandung: PT Alfabet.

Tugiman, Hiro. 2001. Standar Profesional Audit Internal. Yogyakarta: Kanisius. Usman, Zulkarnain. 2013. Pengaruh Sistem Pengendalian Intern terhadap Kinerja Perusahaan pada PT. MNC Sky Vision Cabang Gorontalo.

Zekaj, Selma. 2018. Impact of Audit Quality on Firm Performance. 